\title{
US Resident Perceptions of Dairy Cattle Management Practices
}

\author{
Nicole Olynk Widmar ${ }^{1 *}$, Carissa J. Morgan ${ }^{1}$, Christopher A. Wolf ${ }^{2}$, Elizabeth A. Yeager ${ }^{3}$, \\ S. R. Dominick ${ }^{1}$, Candace C. Croney ${ }^{4}$ \\ ${ }^{1}$ Department of Agricultural Economics, Purdue University, Lafayette, USA \\ ${ }^{2}$ Department of Agricultural, Food, and Resource Economics, Michigan State University, East Lansing, USA \\ ${ }^{3}$ Department of Agricultural Economics, Kansas State University, Manhattan, USA \\ ${ }^{4}$ Center for Animal Welfare Science, Purdue University, Lafayette, USA \\ Email: ^nwidmar@purdue.edu, cmccay@purdue.edu, sdominic@purdue.edu,wolfch@msu.edu, eyeager@ksu.edu, \\ ccroney@purdue.edu
}

How to cite this paper: Widmar, N.O., Morgan, C.J., Wolf, C.A., Yeager, E.A., Dominick, S.R. and Croney, C.C. (2017) US Resident Perceptions of Dairy Cattle Management Practices. Agricultural Sciences, 8, 645-656. https://doi.org/10.4236/as.2017.87049

Received: June 14, 2017

Accepted: July 24, 2017

Published: July 27, 2017

Copyright (c) 2017 by authors and Scientific Research Publishing Inc. This work is licensed under the Creative Commons Attribution International License (CC BY 4.0).

http://creativecommons.org/licenses/by/4.0/ (c) (i) Open Access

\begin{abstract}
As public perception continues to shape the dairy industry, an understanding of consumer views and purchasing behaviors is critically important. The objectives of this paper are to: 1) summarize consumer perceptions or views of 12 common dairy cattle management practices (humane methods of slaughter, humane transportation, increased pen stall or size, access to pasture, feeding of a GMO-free diet, feeding of an organic diet, feeding of a diet the animal would naturally consume, ability to interact with other animals of the same species, access to fresh water at all times, tail docking, use of antibiotics for sick animals, and dehorning), and 2) analyze relationships between respondent's household demographic characteristics and perceptions of three specific contentious dairy practices, including antibiotic use, tail docking, and dehorning. An online, national survey was used to collect data on household demographics, dairy consumption and purchasing behavior, and perceptions of dairy production practices from 1201 US residents. The findings of this study indicate that $87 \%$ of participants consumed dairy products. Of these respondents, $12 \%$ had altered their consumption of dairy products over the past three years because of animal welfare concerns and $10 \%$ had done so due to food safety concerns. Respondents perceived tail docking and dehorning to have the least beneficial and most negative implications for dairy cattle welfare of the dairy production practices considered.
\end{abstract}

\section{Keywords}

Dairy Cattle Welfare, Public Perceptions, Tail Docking, Dehorning 


\section{Introduction}

Societal pressures have led the US dairy industry to invest resources into better understanding perceptions and demands of their industry stakeholders. Knowledge about public perceptions of dairy practices is also needed to inform onfarm decision-making, which enhances public trust and allows farmers to maintain their social license to operate [1]. People appear to be particularly attentive to dairy cattle welfare issues compared to those of other livestock species [2]. For example, Wolf et al. [1] found that $63.4 \%$ of their respondents $(n=1201)$ were concerned about dairy cattle welfare. Interest in dairy cattle well-being may be partly because the products derived are often fed to children and possibly, because there is less of a ready association between dairy products and slaughter (than exists for meat production) [3].

However, clear disconnects are evident between the views of many members of the public and those of the dairy industry relative to the quality of life offered to cows, indicating the need for greater understanding of stakeholders' values, perceptions, and demand for product attributes. "In some cases non-industry groups decry standard industry practices as abusive and call for more humane treatment of animals, while stakeholders within the dairy industry maintain that practices conform to high standards of care. This type of disagreement is likely to be frustrating for both sides and unhelpful in the development and implementation of welfare improvements" [4]. Wolf et al. [1] and McKendree et al. [5] found evidence that demographic factors, such as gender, age, income, and experience with aspects of animal welfare influenced views on livestock animal production processes. Thus, understanding how demographic and other factors potentially influence perceptions of dairy cattle production processes may be important to ensure that dairy farm decision-making is keeping with public expectations.

Given the pressure to address animal welfare concerns and move towards assurance of welfare practices and/or standards for dairy cattle, research efforts have been made to contribute to more economical and efficient ways of meeting societal acceptance of modern dairy farming practices. To this end, many practices have been assessed in past work focused on milk production, including grazing, rBST/rBGH-free production, food safety claims, farm proximity (local production), and antibiotic use [2] [6]. However, consumer perceptions of other production processes employed on US dairy farms, such as dehorning, size of pen space provided to cattle, and interactions with other animals remain unstudied. Many of these practices have become increasingly contentious in popular press and media [7] [8] [9].

The objectives of this analysis are to: 1) summarize consumer perceptions or views of 12 common dairy cattle management practices, and 2) analyze possible relationships between respondents' household demographic characteristics and perceptions of three contentious dairy practices, specifically antibiotic use, tail docking, and dehorning. 


\section{Materials and Methods}

An online national survey was used to collect data on household demographics, dairy consumption and purchasing behavior, and perceptions of dairy production practices from 1201 US residents in April 2015. Researchers at Purdue University designed and pre-tested the survey, then facilitated data collection through the Qualtrics online platform. The sample of respondents was obtained through Lightspeed GMI, managers of a large proprietary opt-in panel. In total, 1713 people clicked the link to the survey which was e-mailed to them by Lightspeed GMI. Of those 1713 a total of 1201 people completed the survey, which resulted in a $70 \%$ completion rate. The survey was conducted online to facilitate data collection for a national sample and allow randomization of the order of questions and possible responses. Surveys conducted via the Internet are becoming more widespread due to faster completion times and lower costs compared to other approaches to public data collection [2] [5] [10] [11] [12]. Furthermore, internet surveys have been found to not exhibit nonresponse bias [13]. The sample was targeted, through the use of respondent quotas (within the Qualtrics platform), to be representative of US households in terms of gender, age, income, and region of residency.

Demographic information including gender, age, income, education level, and region of residence was collected. Also, respondents were asked if they or someone in their household consumed dairy products. For those respondents that indicated household dairy product consumption, they were also asked if they or a member of their household had altered their dairy consumption over the past three years due to animal welfare/handling concerns and/or food safety concerns.

This study sought to identify respondents' perceptions of humane animal treatment relative to their shopping preferences. In an earlier study, Roberts [14] profiled socially responsible behaviors in consumers, eliciting participant responses through a series of social/ethical statements. For the purposes of this study a dairy cattle specific social/ethical statement was similarly developed to measure respondents' attitudes about social responsibility for animal well-being. The statement developed and studied was "I actively look to purchase milk products which promote welfare-friendly conditions for the livestock animals used to produce them". Survey participants were asked to respond with either "never true", "rarely true", "sometimes true" or "always true". For analysis and presentation of results, participant responses were grouped into two categories, "never or rarely true" and "always or sometimes true".

Respondent perceptions of the effects of common dairy production practices on dairy cattle welfare were the primary focus of this analysis. Respondents were presented with 12 common dairy production practices, and asked to rank on a Likert scale where 1 was extremely negative and 7 was extremely positive, their effects on dairy cattle welfare. The question, as presented to respondents in the survey instrument, is displayed in Table 1 . The production practices studied included: humane methods of slaughter, humane transportation, increased pen 
Table 1. Survey questions as presented: how do you feel each of the following production processes impacts the welfare of dairy cattle?

\begin{tabular}{|c|c|c|c|c|c|c|c|}
\hline & $\begin{array}{l}\text { Extremely negative } \\
\text { impact on welfare } 1\end{array}$ & 2 & 3 & 4 & 5 & 6 & $\begin{array}{c}\text { Extremely positive } \\
\text { impact on welfare } 7\end{array}$ \\
\hline Humane methods of slaughter & $\mathrm{O}$ & $\mathrm{O}$ & $\mathrm{O}$ & $\mathrm{O}$ & $\mathrm{O}$ & $\mathrm{O}$ & $\mathrm{O}$ \\
\hline Humane transportation & O & $\mathrm{O}$ & O & $\mathrm{O}$ & $\mathrm{O}$ & $\mathrm{O}$ & $\mathrm{O}$ \\
\hline Increased pen or stall size & $\mathrm{O}$ & $\mathrm{O}$ & $\mathrm{O}$ & $\mathrm{O}$ & $\mathrm{O}$ & $\mathrm{O}$ & $\mathrm{O}$ \\
\hline Access to pasture & $\mathrm{O}$ & $\mathrm{O}$ & $\mathrm{O}$ & $\mathrm{O}$ & O & $\mathrm{O}$ & O \\
\hline Fed a GMO-free diet & $\mathrm{O}$ & $\mathrm{O}$ & $\mathrm{O}$ & $\mathrm{O}$ & O & O & $\mathrm{O}$ \\
\hline Fed an organic diet & O & $\mathrm{O}$ & $\mathrm{O}$ & $\mathrm{O}$ & $\mathrm{O}$ & $\mathrm{O}$ & O \\
\hline $\begin{array}{l}\text { Fed a diet the animal would naturally } \\
\text { consume }\end{array}$ & $\mathrm{O}$ & $\mathrm{O}$ & $\mathrm{O}$ & $\mathrm{O}$ & $\mathrm{O}$ & $\mathrm{O}$ & $\mathrm{O}$ \\
\hline $\begin{array}{l}\text { Ability to interact with other animals } \\
\text { of its species }\end{array}$ & $\mathrm{O}$ & $\mathrm{O}$ & O & O & $\mathrm{O}$ & $\mathrm{O}$ & $\mathrm{O}$ \\
\hline Access to fresh water at all times & $\mathrm{O}$ & $\mathrm{O}$ & O & $\mathrm{O}$ & O & O & $\mathrm{O}$ \\
\hline Tail docking & $\mathrm{O}$ & $\mathrm{O}$ & $\mathrm{O}$ & $\mathrm{O}$ & O & $\mathrm{O}$ & $\mathrm{O}$ \\
\hline Use of antibiotics for sick animals & $\mathrm{O}$ & O & $\mathrm{O}$ & O & O & O & $\mathrm{O}$ \\
\hline Dehorning & $\mathrm{O}$ & $\mathrm{O}$ & $\mathrm{O}$ & $\mathrm{O}$ & $\mathrm{O}$ & $\mathrm{O}$ & $\mathrm{O}$ \\
\hline
\end{tabular}

stall or size, access to pasture, feeding a GMO-free diet, feeding an organic diet, feeding a diet the animal would naturally consume, ability to interact with other cattle (other animals of their same species), access to fresh water at all times, tail docking, use of antibiotics for sick animals, and dehorning. In order to develop categories of perceptions, including negative, neutral, and positive, the seven point Likert scale was aggregated; specifically, Likert scale responses of 1, 2, or 3 were aggregated into negative, responses of 4 were considered neutral, and responses of 5, 6, or 7 were aggregated into the category of positive.

Relationships between variables, including demographics, social/ethical behaviors, and perceptions of common dairy production practices on dairy cattle welfare were investigated in this study. Survey responses were summarized and cross-tabulations were created to study the relationships between variables.

Logit models can estimate the impact of exogenous variables on a binary dependent variable. For this study, three separate models were estimated for the dairy cattle management practices of tail docking, use of antibiotics for sick animals, and dehorning. The binary dependent variable was developed using the Likert scale results, with one indicating those who ranked the selected dairy cattle management practice as positive for animal welfare (Likert rank of 5 to 7 ). All other rankings would be represented by zero.

In the logit models, $y^{*}$ represents a latent variable, or unobserved variable [15]. Using a vector of independent variables $X$, and assuming $e$ is independently distributed, $y^{*}$ can be estimated as:

$$
y^{*}=\beta_{0}+\beta X+e
$$


The results of the estimation will predict the probability of obtaining the specified outcome for $y^{*}$. For a binary variable, the probability that $y^{*}$ will equal 1 can be represented by [15]:

$$
\operatorname{Pr}(y=1 \mid X)=\frac{\mathrm{e}^{\beta X}}{1+\mathrm{e}^{\beta X}}
$$

The coefficients, $\beta$, represent the directional contribution of each variable but not the magnitude. All models were estimated in STATA (14.2) statistical software [16]. Marginal effects were estimated using STATA in order to determine the marginal contribution of each variable. Each logit model estimated included nine explanatory variables. Gender of the respondent was included as a binary variable (female was the binary variable with one representing being female). The age variables, 25 to 44,45 to 64 , and over 65 , were all binary variables for which one represented being a member of each group, respectively (and zero otherwise), while the age group of 18 to 24 year olds was omitted. Education was included as a binary variable in which having a college degree was represented by one (and zero otherwise).

Four household consumption statements were included to understand if consumer behavior is reflective of their perceptions of dairy cattle management practices. Each of the four statements was coded and incorporated into the model as a binary variable in which one represented an affirmative response to the statements surrounding whether the household consumed dairy products, consumed dairy products from farms promoting welfare, had made changes to their dairy consumption due to animal welfare concerns (in the past three years), and/or made changes to their dairy consumption due to food safety concerns (in the past three years).

\section{Results and Discussion}

\subsection{Summary Statistics}

Summary statistics of respondent $(\mathrm{n}=1201)$ demographics are provided in Table 2. Fifty-one percent of respondents were female, which is identical to the US Census Bureau figures [17]. The percentage of respondents reporting their age at the time of participation in each of the four age brackets provided were identical to the proportions of the US population in these brackets, according to the US Census [17]. Household incomes were collected in seven categories: less than $\$ 25,000$ (23\% of respondents), $\$ 25,000$ to $\$ 34,999$ (10\%), $\$ 35,000$ to $\$ 49,000$ (14\%), $\$ 50,000$ to $\$ 74,999$ (18\%), $\$ 75,000$ to $\$ 99,999$ (12\%), $\$ 100,000$ to $\$ 149,999$ (13\%), and $\$ 150,000$ or more (10\%). The proportion of the sample within each household income category was identical to the proportions of the population in each bracket, as reported by the US Census [17].

In total, the respondent sample obtained was more educated than the US population, according to the US Census [17]. The majority of participants, $57 \%$, reported holding a higher education degree (highest level received options were trade, associate's, bachelor's, master's, or $\mathrm{PhD}$ ). The over-education of the 
Table 2. Summary demographics.

\begin{tabular}{|c|c|c|}
\hline Variable & Number of Respondents & Percent of Respondents \\
\hline Female & 610 & 51 \\
\hline \multicolumn{3}{|l|}{ Age (in years) } \\
\hline 18 to 24 & 157 & 13 \\
\hline 25 to 44 & 420 & 35 \\
\hline 45 to 64 & 418 & 35 \\
\hline $65+$ & 205 & 17 \\
\hline \multicolumn{3}{|l|}{ Household income } \\
\hline Less than $\$ 25,000$ & 280 & 23 \\
\hline$\$ 25,000$ to $\$ 34,999$ & 125 & 10 \\
\hline$\$ 35,000$ to $\$ 49,999$ & 164 & 14 \\
\hline$\$ 50,000$ to $\$ 74,999$ & 218 & 18 \\
\hline$\$ 75,000$ to $\$ 99,999$ & 147 & 12 \\
\hline$\$ 100,000$ to $\$ 149,999$ & 154 & 13 \\
\hline$\$ 150,000$ or more & 113 & 10 \\
\hline \multicolumn{3}{|l|}{ US geographic region of residence } \\
\hline Northeast & 215 & 18 \\
\hline South & 455 & 38 \\
\hline Midwest & 268 & 22 \\
\hline West & 263 & 22 \\
\hline \multicolumn{3}{|l|}{ Education } \\
\hline Did not graduate from high school & 24 & 2 \\
\hline Graduated from high school, did not attend college & 220 & 19 \\
\hline Attended college, no degree earned & 250 & 21 \\
\hline Attended college, associates or trade degree earned & 159 & 13 \\
\hline Attended college, bachelor's (B.S. or B.A.) degree earned & 339 & 28 \\
\hline Attended college, advanced (M.S., Ph.D. or Law) degree earned & 195 & 16 \\
\hline Other & 14 & 1 \\
\hline \multicolumn{3}{|l|}{ Household dairy product consumption } \\
\hline Yes, at least one member of my household consumes dairy products & 1044 & 87 \\
\hline No member(s) of my household consume dairy & 70 & 6 \\
\hline $\begin{array}{l}\text { I do not know if anyone in my household consumes dairy, but I would be } \\
\text { willing to purchase/consume }\end{array}$ & 48 & 4 \\
\hline $\begin{array}{l}\text { I do not know if anyone in my household consumes dairy, but I would not } \\
\text { be willing to purchase/consume }\end{array}$ & 39 & 3 \\
\hline
\end{tabular}

sample, relative to the US population, could be in-part due to the survey taking place online, potentially restricting accessibility to residents with ready Internet access, time available online, interest in voluntary participation, ability to read 
and comprehend the survey, and/or other reasons. With respect to US region of residence, $38 \%$ were from the South, $22 \%$ from both the Midwest and the West, and $18 \%$ from the Northeast. Each region's representation in the sample was identical to regional residences reported in the US population [17]. Participants were also asked if there were children in their households; the majority, $68 \%$ of households, did not have children, while the remaining $32 \%$ did.

Respondents were asked about their household dairy product consumption. The majority, $87 \%$ of respondents, indicated that their household consumed dairy products, while only $6 \%$ did not. The remaining $7 \%$ did not know about their household dairy consumption, and of this group, $4 \%$ indicated being either willing to purchase or consume dairy products while $3 \%$ was unwilling to purchase or consume such products.

Those respondents who indicated that they or their household consumed dairy were asked a follow up question about whether they or anyone in their household had altered their consumption of dairy products because of concerns about animal welfare or food safety. Twelve percent of respondents' households reportedly had altered their dairy product consumption in the past three years as a result of animal welfare concerns, while $10 \%$ had altered consumption due to food safety concerns. Most (63\%) had not altered consumption for either reason, and $11 \%$ reported that they did not know if the household had altered consumption.

\subsection{Perceptions of Dairy Cattle Management Practices}

Twelve dairy cattle management practices were investigated in this analysis, namely humane methods of slaughter, humane transportation, increased pen stall or size, access to pasture, feeding of a GMO-free diet, feeding of an organic diet, feeding of a diet the animal would naturally consume, ability to interact with other animals of its species, access to fresh water at all times, tail docking, use of antibiotics for sick animals, and dehorning. Table 1 summarizes responses for each of these 12 cattle management practices as either negative (rank of 1 to 3), neutral (rank of 4), or positive (rank of 5 to 7). In addition, the mean of all responses (using the original 1 to 7 scale) is presented for each practice across all 1201 respondents. With the exception of tail docking and dehorning, over $50 \%$ of respondents felt that the practices of focus contributed positively to dairy cattle welfare. More than $30 \%$ of respondents felt that tail docking and dehorning contributed negatively to dairy cattle welfare and less than $30 \%$ indicated that these practices had positive effects on dairy cows.

For seven of the 12 practices, fewer than $10 \%$ of respondents perceived there to be negative implications for dairy cattle welfare. Those practices with more than $10 \%$ of respondents reporting negative implications for welfare were feeding of a GMO-free diet, feeding of an organic diet, the use of antibiotics for sick animals, tail docking and dehorning. Given that numerous studies have reported welfare problems, such as pain in cattle as a function of tail docking and dehorning [18] [19] [20] [21], respondents' views of these as impinging on cow 
welfare were unsurprising. The views that feeding (GMO-free) diets that are often publicly lauded as safer, healthier or more sustainable [22], and treating of ill animals with antibiotics negatively impacted cattle welfare were unexpected and difficult to explain. However, it is possible that at least some of these respondents may have been intolerant of any usage of antibiotics in animal production and that some may have been expressing opposition to anti-GMO or pro- organic campaigns.

\subsection{Explaining Views of Management Practices}

From Figure 1, it is clear that tail docking, antibiotic use, and dehorning were viewed as more detrimental to dairy cattle welfare than the other practices considered. As such, logit estimation was used to examine factors related to the views of these practices where, as a reminder, the dependent variable was one if the practice was positive for cattle welfare and zero if it was negative or neutral.

Two of the three logit models were found to be significant with $<0.0001$ likelihood ratio $\mathrm{Chi}^{2}$ test outcomes, for which the hypothesis that the coefficients in each model are zero is rejected (Table 3 ). The model predicting the likelihood that use of antibiotics for sick animals would be seen positively had the lowest likelihood ratio $\mathrm{Chi}^{2}$ test outcome, but the hypothesis can still be rejected with $95 \%$ confidence. This suggests that while the model is still predictive, other variables may exist that are more predictive than the ones included here. Certainly, with

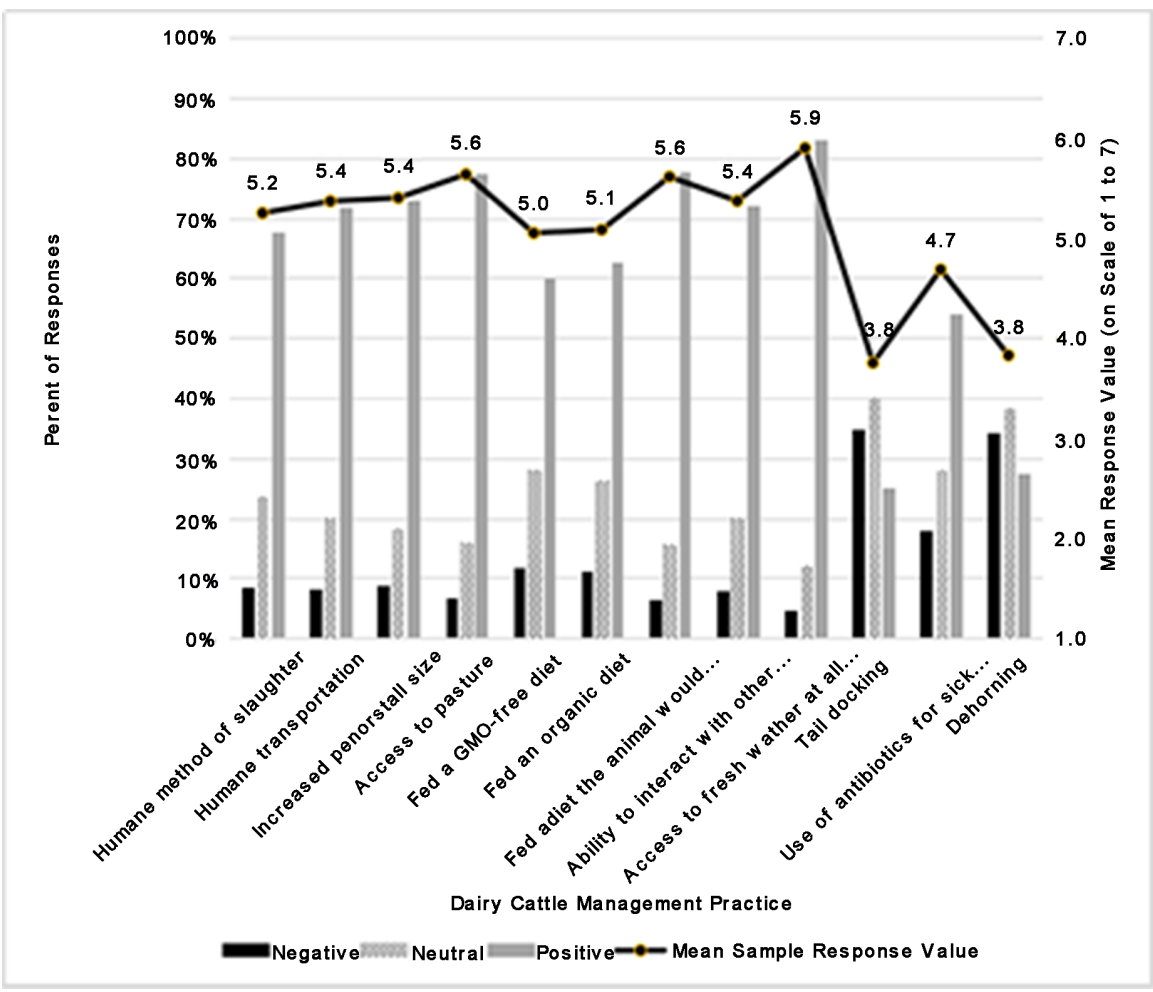

Figure 1. Summary of respondent perceptions of dairy cattle management practices ( $\mathrm{n}=$ 1201) $)^{1}$. For analysis purposes, responses were aggregated into negative (rank of 1 to 3 ), neutral (rank of 4), or positive (rank of 5 to 7 ). 
Table 3. Logit model coefficient estimates and marginal effects.

\begin{tabular}{|c|c|c|c|c|c|c|}
\hline \multirow[b]{2}{*}{ Variable } & \multicolumn{2}{|c|}{ Tail docking } & \multicolumn{2}{|c|}{ Use antibiotics for sick animals } & \multicolumn{2}{|c|}{ Dehorning } \\
\hline & $\begin{array}{l}\text { Coefficient } \\
\quad \text { (SE) }\end{array}$ & $\begin{array}{l}\text { Marginal } \\
\text { effect (SE) }\end{array}$ & $\begin{array}{l}\text { Coefficient } \\
\quad \text { (SE) }\end{array}$ & $\begin{array}{l}\text { Marginal } \\
\text { effect (SE) }\end{array}$ & $\begin{array}{l}\text { Coefficient } \\
\quad(\mathrm{SE})\end{array}$ & $\begin{array}{l}\text { Marginal } \\
\text { effect (SE) }\end{array}$ \\
\hline Female & $\begin{array}{l}-0.6450^{* * *} \\
(0.1471)\end{array}$ & $\begin{array}{l}-0.1102^{* * *} \\
(0.0250)\end{array}$ & $\begin{array}{l}-0.2008^{*} \\
(0.1186)\end{array}$ & $\begin{array}{l}-0.0498^{*} \\
(0.0294)\end{array}$ & $\begin{array}{l}-0.6333^{* * *} \\
(0.1404)\end{array}$ & $\begin{array}{l}-0.1191^{* * *} \\
(0.0262)\end{array}$ \\
\hline Age 25 to 44 & $\begin{array}{c}0.2963 \\
(0.2179)\end{array}$ & $\begin{array}{c}0.0517 \\
(0.0390)\end{array}$ & $\begin{array}{c}0.0290 \\
(0.1933)\end{array}$ & $\begin{array}{c}0.0072 \\
(0.0480)\end{array}$ & $\begin{array}{c}0.1610 \\
(0.2083)\end{array}$ & $\begin{array}{c}0.0306 \\
(0.0401)\end{array}$ \\
\hline Age 45 to 64 & $\begin{array}{l}-0.6466^{* * *} \\
(0.2343)\end{array}$ & $\begin{array}{l}-0.1041^{* * *} \\
(0.0354)\end{array}$ & $\begin{array}{l}-0.2502 \\
(0.1932)\end{array}$ & $\begin{array}{l}-0.0622 \\
(0.0480)\end{array}$ & $\begin{array}{l}-0.6198^{* * *} \\
(0.2194)\end{array}$ & $\begin{array}{l}-0.1109 * * * \\
(0.0371)\end{array}$ \\
\hline Age over 65 & $\begin{array}{l}-0.4744^{*} \\
(0.2721)\end{array}$ & $\begin{array}{l}-0.0737^{* *} \\
(0.0382)\end{array}$ & $\begin{array}{c}0.1100 \\
(0.2189)\end{array}$ & $\begin{array}{c}0.0272 \\
(0.0540)\end{array}$ & $\begin{array}{l}-0.7205^{* * *} \\
(0.2622)\end{array}$ & $\begin{array}{l}-0.1190^{* * *} \\
(0.0373)\end{array}$ \\
\hline College degree & $\begin{array}{c}0.1848 \\
(0.1507)\end{array}$ & $\begin{array}{c}0.0312 \\
(0.0252)\end{array}$ & $\begin{array}{c}0.1731 \\
(0.1211)\end{array}$ & $\begin{array}{c}0.0430 \\
(0.0301)\end{array}$ & $\begin{array}{l}-.0494 \\
(0.1430)\end{array}$ & $\begin{array}{c}-0.0093 \\
0.0269\end{array}$ \\
\hline $\begin{array}{l}\text { Consumes dairy products from } \\
\text { farms that promote welfare }\end{array}$ & $\begin{array}{l}0.7796^{* * *} \\
(0.1520)\end{array}$ & $\begin{array}{l}0.1341^{* * *} \\
(0.0260)\end{array}$ & $\begin{array}{c}0.1956 \\
(0.1235)\end{array}$ & $\begin{array}{c}0.0485 \\
(0.0306)\end{array}$ & $\begin{array}{l}0.4675^{* * *} \\
(0.1444)\end{array}$ & $\begin{array}{c}0.0882^{* * *} \\
(0.0272)\end{array}$ \\
\hline Household consumes dairy & $\begin{array}{l}-0.6678^{* * *} \\
(0.1969)\end{array}$ & $\begin{array}{l}-0.1288^{* * *} \\
(0.0420)\end{array}$ & $\begin{array}{c}0.2890 \\
(0.1235)\end{array}$ & $\begin{array}{c}0.0721 \\
(0.0447)\end{array}$ & $\begin{array}{c}-0.5905^{* * *} \\
(0.1915)\end{array}$ & $\begin{array}{c}-0.1220^{* * *} \\
(0.0428)\end{array}$ \\
\hline $\begin{array}{l}\text { Made changes to their dairy } \\
\text { consumption due to animal } \\
\text { welfare concerns }\end{array}$ & $\begin{array}{c}0.5349^{* * *} \\
(0.2025)\end{array}$ & $\begin{array}{l}0.1011^{* *} \\
(0.0419)\end{array}$ & $\begin{array}{l}-0.0266 \\
(0.1886)\end{array}$ & $\begin{array}{l}-0.0066 \\
(0.0469)\end{array}$ & $\begin{array}{c}0.6077^{* * *} \\
(0.1981)\end{array}$ & $\begin{array}{c}0.1262^{* * *} \\
(0.0446)\end{array}$ \\
\hline $\begin{array}{l}\text { Made changes to their dairy } \\
\text { consumption due to food safety } \\
\text { concerns }\end{array}$ & $\begin{array}{c}0.5958^{* * *} \\
(0.2149)\end{array}$ & $\begin{array}{l}0.1144^{* *} \\
(0.0457)\end{array}$ & $\begin{array}{c}0.3222 \\
(0.2027)\end{array}$ & $\begin{array}{l}-0.0066 \\
(0.0469)\end{array}$ & $\begin{array}{c}0.6086^{* * *} \\
(0.2105)\end{array}$ & $\begin{array}{c}0.1269^{* * *} \\
(0.0477)\end{array}$ \\
\hline Constant & $\begin{array}{c}-0.7579 * * * \\
(0.2608)\end{array}$ & & $\begin{array}{l}-0.1485 \\
(0.2314)\end{array}$ & & $\begin{array}{l}-0.2950 \\
(0.2490)\end{array}$ & \\
\hline Log Likelihood & -586.6781 & & -804.8707 & & -631.0831 & \\
\hline Pseudo $\mathrm{R}^{2}$ & 0.1084 & & 0.0114 & & 0.0849 & \\
\hline Prob $>\mathrm{Chi}^{2}$ & 0.0000 & & 0.0289 & & 0.0000 & \\
\hline
\end{tabular}

For all variables the marginal effect is for discrete change of dummy variable from 0 to $1 \mathrm{p}$-values: ${ }^{*} \mathrm{p}<0.10,{ }^{* *} \mathrm{p}<0.05,{ }^{* * *} \mathrm{p}<0.01$.

respect to overall significance and the significance of individual variables in predicting the stated perceptions surrounding dairy practices, the model for antibiotic use is quite different from the models for perceptions of dehorning or tail docking. Only a single variable investigated (gender of respondent) was significant in predicting the stated welfare perceptions of antibiotic use for dairy cattle.

Across all models, women were less likely to agree that tail docking, use of antibiotics for sick animals, and dehorning had positive impacts on dairy cattle welfare. Being female marginally decreased the likelihood of agreement by $11 \%$, $5 \%$, and $12 \%$, respectively. Belonging to the 25 to 44 age bracket and having a college degree were not significant in any model. However, being 45 to 64 and being over 65 were significant and negative for the models predicting positive perceptions of tail docking and dehorning. Overall findings surrounding age of respondents and likelihood that practices were seen as positive for dairy cattle welfare suggest that being in the older age categories was related to being less likely to see tail docking and dehorning as having a positive impact.

Interestingly, consuming dairy products from farms that promote animal welfare was positive and significant to the tail docking and dehorning models. In 
other words, consuming products from farms that promote animal welfare was associated with reporting that tail docking and dehorning have positive welfare impacts. For tail docking, consuming dairy products from farms that promote animal welfare increased the likelihood of believing tail docking had a positive impact by $13 \%$; for dehorning the likelihood increased by $8 \%$. In contrast, if the households consumed no dairy products at all, the likelihood of perceiving tail docking and dehorning as positive with regard to impacts on cattle welfare decreased by $13 \%$ and $12 \%$, respectively.

These results indicate that tail docking and dehorning were practices of concern for many respondents. This finding may be related to the possibility of respondents seeing news coverage on animal welfare issues and undercover videos from dairy farms. For example, the state of California mandated dairy farmers stop tail docking as of January 1, 2010, while the National Milk Producers Federation announced in 2015 that tail docking among their member-farms would end nation-wide on December 31, 2016 [23].

Antibiotic use is of particular interest in recent years as the Food and Drug Administration has taken steps towards fundamentally changing how medically important antibiotics can be used legally in feed or water for food-producing animals [24]. The Veterinary Feed Directive (VFD) is an important part of the overall plan to ensure the judicious use of medically important antimicrobials in food-animals. Given the importance of antimicrobials discussed in popular media with regard to human health coupled with the recent movements to change how medically important antimicrobials are utilized in animals, the interest in antibiotic use in dairy cows is unsurprising. Awareness of public perceptions about management practices, such as antibiotic use, dehorning, and tail docking, will assist in designing industry policies to maintain the social license to produce as well as access to markets.

\section{Conclusion}

The findings of this study indicated that $87 \%$ of respondents consumed dairy products. Of these respondents, $12 \%$ had altered their consumption of dairy products over the past three years because of animal welfare concerns, and 10\% had done so due to food safety concerns. Of the dairy production practices of interest (humane methods of slaughter, humane transportation, increased pen stall or size, access to pasture, feeding of a GMO-free diet, feeding of an organic diet, feeding of a diet the animal would naturally consume, ability to interact with other animals of its species, access to fresh water at all times, tail docking, use of antibiotics for sick animals, and dehorning), respondents perceived tail docking and dehorning to have the least beneficial and most negative implications for cattle welfare. A higher percentage of female than male respondents reported believing that these practices decreased dairy cattle welfare, but there was less consistency in reporting trends of the effects of these practices across age and education brackets. Recognizing how the public perceives dairy production can enable dairy industry leaders to be more responsive to their stakeholders' demands. 


\section{References}

[1] Wolf, C.A., Tonsor, G.T., McKendree, M.G.S., Thomson, D.U. and Swanson, J.C. (2016) Public and Farmer Perceptions of Dairy Cattle Welfare in the United States. Journal of Dairy Science, 99, 1-12. https://doi.org/10.3168/jds.2015-10619

[2] Olynk, N.J., Tonsor, G.T. and Wolf, C.A. (2010) Consumer Willingness to Pay for Livestock Credence Attribute Claim Verification. Journal of Agricultural and Resource Economics, 35, 261-280.

[3] Cook-Mowery, C., Olynk, N. and Wolf, C. (2008) Farm-Level Contracting for Production Process Attributes: An Analysis of the rbST Situation in Michigan Milk Production. Journal of Food Law and Policy, 4,177-208.

[4] Ventura, B.A., von Keyserlingk, M.A.G. and Weary, D.M. (2015) Animal Welfare Concerns and Values of Stakeholders within the Dairy Industry. Journal of Agricultural and Environmental Ethics, 28,109-126. https://doi.org/10.1007/s10806-014-9523-x

[5] McKendree, M.G.S., Croney, C.C. and Widmar, N.O. (2014) Effects of Demographic Factors and Information Sources on United States Consumer Perceptions of Animal Welfare. Journal of Animal Science, 92, 3161-3173. https://doi.org/10.2527/jas.2014-6874

[6] Wolf, C.A., Tonsor, G.T. and Olynk, N.J. (2011) Understanding US Consumer Demand for Milk Production Attributes. Journal of Agricultural and Resource Economics, 36, 326-342.

[7] Huffington Post (2013) Ryan Gosling Fights Cow "Dehorning” in Letter Shared by PETA. Huff Post Green.

http://www.huffingtonpost.com/2013/04/03/ryan-gosling--cow-dehorning-letter-pe ta $\mathrm{n}$ 3010066.html?view=screen

[8] Miller, D.J. (2014) Great Lakes Cheese is "Outraged" over Mistreatment of Cows. Cleveland Plain Dealer. November 11, 2014.

http://www.cleveland.com/metro/index.ssf/2014/11/great lakes cheese is outraged $\underline{. h t m l}$

[9] Paul, J. (2015) Colorado Authorities Investigating Dairy Cow Abuse Video: Workers fired. The Denver Post. June 11, 2015.

http://www.denverpost.com/news/ci 28295679/colorado-authorities-investigatingdairy-plant-abuse-video-workers?source=infinite-up.

[10] Gao, Z. and Schroeder, T. (2009) Effects of Additional Quality Attributes on Consumer Willingness-to-Pay for Food Labels. American Journal of Agricultural Economics, 91, 795-809. https://doi.org/10.1111/j.1467-8276.2009.01259.x

[11] Louviere, J.J., Islam, T., Wasi, N., Street, D. and Burgess, L. (2008) Designing Discrete Choice Experiments: Do Optimal Designs Come at a Price? Journal of Consumer Research, 35, 360-375. https://doi.org/10.1086/586913

[12] Tonsor, G.T. and Wolf, C.A. (2010) Drivers of Resident Support for Animal Care Oriented Ballot Initiatives. Journal of Agricultural and Applied Economics, 42, 419428. https://doi.org/10.1017/S1074070800003606

[13] Hudson, D., Seah, L., Hite, D. and Haab, T. (2004) Telephone Presurveys, Self-Selection, and Non-Response Bias to Mail and Internet Surveys in Economic Research. Applied Economics Letters, 11, 237-240. https://doi.org/10.1080/13504850410001674876

[14] Roberts, J.A. (1995) Profiling Levels of Socially Responsible Consumer Behavior: A Cluster Analytic Approach and Its Implications for Marketing. Journal of Marketing Theory and Practice, 3, 97-117. 
https://doi.org/10.1080/10696679.1995.11501709

[15] Wooldridge, J.M. (2009) Introductory Econometrics: A Modern Approach. 5th Edition, South-Western Cengage Learning, Mason.

[16] StataCorp (2015) Stata Statistical Software: Release 14. StataCorp LP, College Station.

[17] US Census Bureau (2015) Topics. https://www.census.gov/topics/population.html

[18] Eicher, S.D., Morrow-Tesch, J.L., Albright, J.L. and Williams, R.E. (2001) TailDocking Alters Fly Numbers, Fly-Avoidance Behaviors, and Cleanliness, But Not Physiological Measures. Journal of Dairy Science, 84, 1822-1828. https://doi.org/10.3168/jds.S0022-0302(01)74621-8

[19] Stull, C.L., Payne, M.A., Berry, S.L. and Hullinger, P.J. (2002) Evaluation of the Scientific Justification for Tail Docking in Dairy Cattle. American Veterinary Medical Association, 220, 1298-1303. https://doi.org/10.2460/javma.2002.220.1298

[20] Faulkner, P.M. and Weary, D.M. (2000) Reducing Pain after Dehorning in Dairy Calves. Journal of Dairy Science, 83, 2037-2041. https://doi.org/10.3168/jds.S0022-0302(00)75084-3

[21] Heinrich, A., Duffield, T.F., Lissemore, K.D. and Millman, S.T. (2010) The Effect of Meloxicam on Behavior and Pain Sensitivity of Dairy Calves Following Cautery Dehorning with a Local Anesthetic. Journal of Dairy Science, 93, 2450-2457.

https://doi.org/10.3168/jds.2009-2813

[22] Bourn, D. and Prescott, J. (2002) A Comparison of the Nutritional Value, Sensory Qualities, and Food Safety of Organically and Conventionally Produced Foods. Critical Reviews in Food Science and Nutrition, 42, 1-34. https://doi.org/10.1080/10408690290825439

[23] Sjostrom, L. (2015) Tail Docking Ends for NMPF Members, FARM Participants in 2016. Dairy Herd Management.

http://www.dairyherd.com/news/tail-docking-ends-nmpf-members-farm-participa nts-2016

[24] Food and Drug Administration (2015) FACT SHEET: Veterinary Feed Directive Final Rule and Next Steps.

http://www.fda.gov/AnimalVeterinary/DevelopmentApprovalProcess/ucm449019.h $\underline{\mathrm{tm}}$

\section{Submit or recommend next manuscript to SCIRP and we will provide best} service for you:

Accepting pre-submission inquiries through Email, Facebook, LinkedIn, Twitter, etc. A wide selection of journals (inclusive of 9 subjects, more than 200 journals)

Providing 24-hour high-quality service

User-friendly online submission system

Fair and swift peer-review system

Efficient typesetting and proofreading procedure

Display of the result of downloads and visits, as well as the number of cited articles

Maximum dissemination of your research work

Submit your manuscript at: http://papersubmission.scirp.org/

Orcontact as@scirp.org 